\title{
Effect of joint and isolated irregularities of the track on the wear of rails in curves
}

\author{
Dmytro Potapov ${ }^{1, *}$, Sergij Panchenko ${ }^{1}$, Yaroslav Leibuk ${ }^{1}$, Yuseph Tuley ${ }^{2}$, and Pavel Plis ${ }^{3}$ \\ ${ }^{1}$ Ukrainian State University of Railway Transport, Feierbakh Square 7, 61050, Kharkiv, Ukraine \\ ${ }^{2}$ Chief Engineer - First Deputy Director of regional branch "Pivdenna Zaliznytsia" PJSC \\ "UKRZALIZNYTSIA", str. Evgena Kotlyara, 7, 61052, Kharkiv, Ukraine \\ ${ }^{3}$ Kupianskaya Railway Machine Station 133, Str. Sovetskaya, 14, 63709, Kupiansk, Ukraine
}

\begin{abstract}
The purpose of the work is to identifying causes of intensive lateral wear of rails and other track failures in short radius curves using numerical methods. The study has been conducted for the most common type of rolling stock: four-axle freight cars on TsNII-Ch3 bogies, transportation of which makes $75-90 \%$ of freight load of the track sections. Thus, it is the effect of these cars which is the main cause of the above disorders. To solve the problem, effect of the following parameters of the track plan on dynamic processes of interaction of the track and rolling stock was investigated in the work: effect of the curves radius, the unbalanced accelerations and the width of the track; effect of local joint and smooth irregularities of the track in plan view. The results of numerical studies. A mathematical model of the spatial dynamic system "vehicle-track" has been used to perform the study, which is based on the design diagrams of the track in the form of long rail beams resting on multiple dissipative elastic supporting sleepers with nonlinear characteristics. This model is implemented in the MathCAD software system.
\end{abstract}

\section{Introduction}

The sections of the track in short radius curves (less than $400 \mathrm{~m}$ ) differ significantly from other sections by multiple technical failures, including lateral wear of the rails, derangements in plan view and widening of the railway track, although the total length of curves with radii less than $400 \mathrm{~m}$ is about $2.5 \%$ of the total length of main tracks of the Ukrainian main railways.

The main applicable regulatory document [2] is based on the quasi-static calculation method for the effect of vertical forces. The effect of horizontal lateral forces, including in curves, on the value of normal stresses in the edges of the top and base of the rail is taken into account using correction factors depending on the type of rolling stock and the radii of the curves.

Methods for determining horizontal lateral forces in the curve were further developed in $[3,5,6,8]$, in which vertical and horizontal lateral forces of interaction of rolling stock and

* Corresponding author: ppx_xiit@kart.edu.ua 
tracks were determined using methods of statistical dynamics and the theory of random functions. However, more recent studies [1] have shown that in certain operative conditions, for example, in short radius curves, the principle of superposition is not applicable.

It should be emphasized that, according to some authors $[2,4,7,9]$, the reason of using design diagrams in the form of a beam on elastic foundation was problems in computations when sufficiently powerful computing means were unavailable.

In [1] a mathematical model of the spatial dynamic system "vehicle-track" is presented, which is based on the design diagrams of the track in the form of long rail beams resting on multiple dissipative elastic supporting sleepers with nonlinear characteristics. In addition, the principle of superposition in the dynamic subsystem "vehicle" was not used. The mathematical model is implemented in the MathCAD software system.

The purpose of the work is identifying causes of intensive lateral wear of rails and other track failures in short radius curves using numerical methods. The study has been conducted for the most common type of rolling stock: four-axle freight cars on TsNII-Ch3 bogies, transportation of which makes $75-90 \%$ of freight load of the track sections. Thus, it is the effect of these cars which is the main cause of the above disorders.

To solve the problem, effect of the following parameters of the track plan on dynamic processes of interaction of the track and rolling stock has been investigated in the work:

- effect of curve radius, unbalanced accelerations and track width;

- effect of local joint and smooth irregularities of the track in plan view.

In the short radius curves, due to insufficient flexural stiffness of the joint pads, angleshaped indentations are present practically everywhere in plan view. These "angles" vary from $0.2^{0}$ to $2^{0}$, depending on the type of joint pads (with four or six-bolt joint) and the bolt tension.

Numerical studies were carried out when a four-axle freight car was moving on a curve with a radius of $300 \mathrm{~m}$ in order to detect the effect of these indents. The adopted value of unbalanced acceleration in all cases was $0.4 \mathrm{~m} / \mathrm{s}^{2}$, speed of movement $-17.7 \mathrm{~m} / \mathrm{s}$ with the rise of external rails of $100 \mathrm{~mm}$ and $20,25 \mathrm{~m} / \mathrm{s}$ with the rise of $150 \mathrm{~mm}$. The angle at the joint was taken to be equal to $0.25^{0}$ to $2.0^{\circ}$, which allowed detecting the effect of this parameter on the dynamics processes. The results are shown in Table 1. An example of a diagram of changes in horizontal transverse lateral forces of the first wheel pair in the direction of travel is shown in Fig. 1.

Table 1. Extreme values of directive and lateral forces in the presence of joint irregularities.

\begin{tabular}{|c|c|c|c|c|c|c|c|}
\hline \multirow[b]{2}{*}{ Rail base } & \multirow{2}{*}{$\begin{array}{c}\text { Speed, } \\
\mathrm{m} / \mathrm{s}\end{array}$} & \multirow{2}{*}{$\begin{array}{c}\text { Rise of } \\
\text { external } \\
\text { trail, mm }\end{array}$} & \multirow{2}{*}{$\begin{array}{c}\text { Angle in } \\
\text { the joint, } \\
\text { degree. }\end{array}$} & \multicolumn{3}{|c|}{ Lateral forces, $\mathrm{kN}$} & \multirow{2}{*}{$\begin{array}{c}\text { Total wear } \\
\text { coefficient } \\
\text { kN rad }\end{array}$} \\
\hline & & & & $\begin{array}{c}\text { Directive } \\
\text { forces }\end{array}$ & $\begin{array}{c}\text { External } \\
\text { rail }\end{array}$ & $\begin{array}{c}\text { Internal } \\
\text { rail }\end{array}$ & \\
\hline \multirow{7}{*}{$\begin{array}{c}\text { Wooden } \\
\text { sleepers, } \\
\text { fasteners DO }\end{array}$} & 17.7 & 100 & 0.25 & 15.5 & 20.1 & -8.6 & 2.340 \\
\hline & 17.7 & 100 & 0.5 & 25.5 & 29.5 & -14.6 & 2.5703 \\
\hline & 17.7 & 100 & 0.75 & 50.2 & 41.3 & -16.6 & 3.4705 \\
\hline & 17.7 & 100 & 1.5 & 64.3 & 65.4 & -20.3 & 4.1704 \\
\hline & 17.7 & 100 & 1.75 & 84.6 & 87.7 & -27.3 & 5.4062 \\
\hline & 17.7 & 100 & 2.0 & 106.6 & 120.2 & -39.8 & 5.4067 \\
\hline & 20.25 & 150 & 2.0 & 52.3 & 61.3 & -26.2 & 4.167 \\
\hline \multirow{4}{*}{$\begin{array}{c}\text { Reinforced } \\
\text { concrete } \\
\text { sleepers, } \\
\text { Sh 1-1, } \\
\text { SKD-B } \\
\end{array}$} & 17.7 & 100 & 0.25 & 19.6 & 27.6 & -9.2 & 2.750 \\
\hline & 17.7 & 100 & 0.5 & 29.2 & 38.4 & -16.5 & 2.985 \\
\hline & 17.7 & 100 & 1.5 & 79.6 & 185.4 & -24.5 & 5.112 \\
\hline & 17.7 & 100 & 2.0 & 120.5 & 137.4 & -41.5 & 6.65 \\
\hline
\end{tabular}

The data in the Table 1 show that the increase of the angles in joints in the track with wooden sleepers under other equal conditions causes the growth of lateral forces and the 
total wear coefficient. When the angles change from $0.25^{\circ}$ to $2.0^{\circ}$, directive forces increase 6.87 times, lateral forces -5.98 times, and the total wear coefficient -2.37 .

When reinforced sleepers with SKD65-B fasteners are used, the horizontal lateral forces increase up to $120 \mathrm{kN}$ for directive forces and up to $137 \mathrm{kN}$ for horizontal lateral forces. The total wear coefficient of rails increases by $38 \%$. The interaction of the wheel flange with the top of the rail is definitely of impact nature (Fig. 1).

Thus, in the joints, even with six-bolt joints and high performance bolts, angles of $0.25^{\circ}$ occur. In other conditions, these angles can reach $2.0^{\circ}$. At speeds of $60-70 \mathrm{~km} / \mathrm{h}$, the wear coefficient increases by almost 3 times. These values can be reduced by decreasing flexural stiffness of the joint. Reducing the horizontal transverse rigidity of rail supports is also useful.

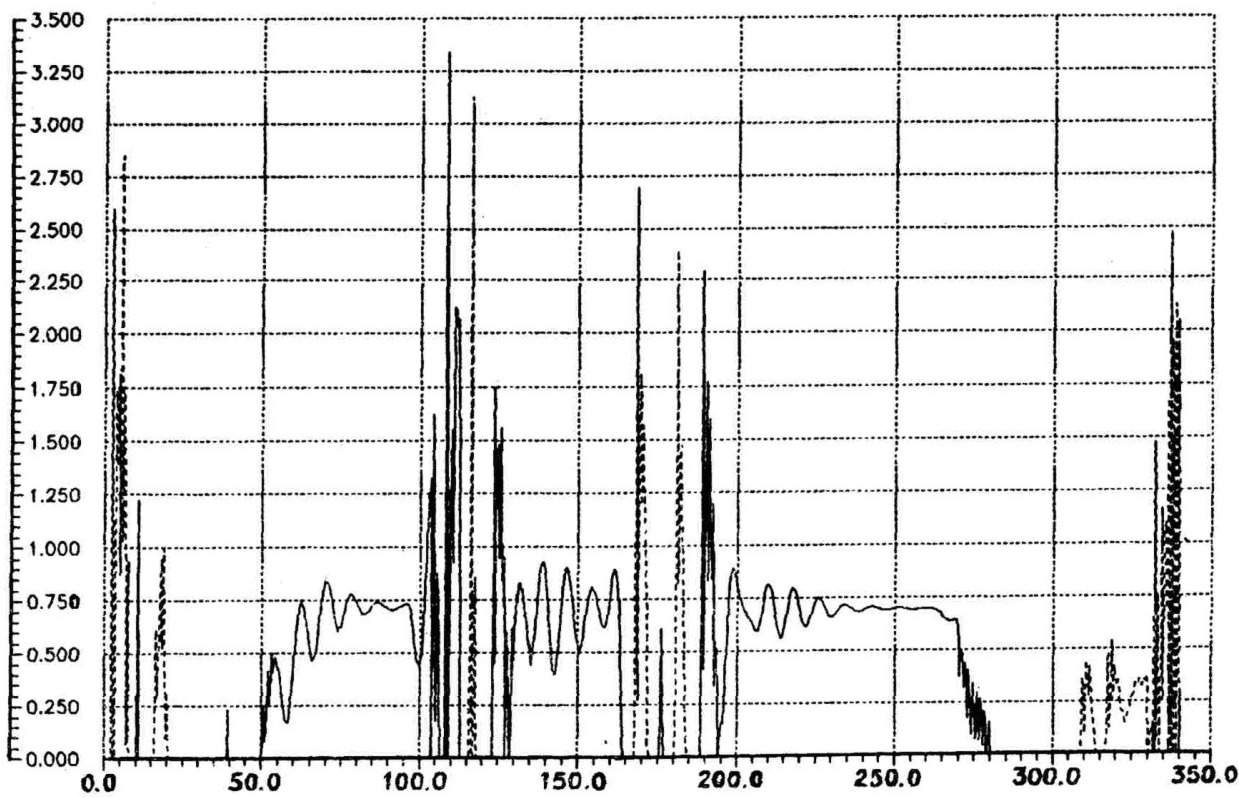

Fig. 1. Diagram of dependences of directive forces on the first wheel in the direction of travel in the areas of joint irregularities

The study of the effect of smooth isolating tracks in plan view was carried out using inequality models that were given in the form of a displaced cosine curve:

$$
\eta(x)=\frac{a_{\text {ner }}}{2}\left(1-\cos \frac{2 \cdot \pi \cdot x}{L}\right)
$$

where $a_{\text {ner }}$ - amplitude of irregularity, (m); $L$ - its total length, (m); $x$ - distance from the beginning of the irregularity to ordinate $\eta(x)$.

Numerical studies have been conducted on the effect of different values of amplitude (from 6 to $24 \mathrm{~mm}$ ) for irregularity of this kind. The length of the inequalities was assumed constant $-20 \mathrm{~m}$. The curve radius was adopted equal to $300 \mathrm{~m}$, the rise of the external rail $110 \mathrm{~mm}$, the traveling speed of the car $-20.3 \mathrm{~m} / \mathrm{s}$.

Moreover, additional calculation has been performed for the option of the curve radius of $600 \mathrm{~m}$ to compare the results. In this case, the speed was adopted at $27.7 \mathrm{~m} / \mathrm{s}$. This option was considered because in the actual operating conditions in curves with radii $R \geq 600$ lateral wear is very slight or absent. 
Track irregularity in plan view increase significantly the curvature of rails in plan view. This leads to an increase in wear coefficients 8.74 times and the emergence of impact forces if up to $118-122 \mathrm{kN}$ for wooden sleepers and 123-135 $\mathrm{kN}$ for reinforced concrete with SKD65-B fasteners.

In addition to studies on determining the allowable values of the parameters of smooth isolated irregularities in plan view, studies have been conducted to identify the most favorable modes of movement of cars on smooth isolated irregularities. For this purpose, studies have been carried out on the effect of the magnitude of unbalanced accelerations on horizontal lateral forces and the total wear coefficient, with constant values of length of irregularity and its amplitudes, and variables of unbalanced accelerations.

In Table 2, the results of the study of parameters during the movement of the calculated car on the short (1-2 m) isolated irregularities in the curve of a radius of $300 \mathrm{~m}$ are given.

During conducting these studies, the curve radius was adopted equal to $300 \mathrm{~m}$, unbalanced acceleration $-0.4 \mathrm{~m} / \mathrm{s}^{2}$, traveling speed $-17.5 \mathrm{~m} / \mathrm{s}$.

Table 2. Effect of short isolated irregularities on the extreme values of horizontal lateral forces and total wear coefficient

\begin{tabular}{|c|c|c|c|c|}
\hline \multirow{2}{*}{$\begin{array}{c}\text { Length of } \\
\text { irregularities, } \mathrm{m}\end{array}$} & \multirow{2}{*}{$\begin{array}{c}\text { Amplitude of } \\
\text { irregularity, } \mathrm{mm}\end{array}$} & \multicolumn{2}{|c|}{$\begin{array}{c}\text { Extreme values of horizontal lateral } \\
\text { forces, } \mathrm{kN}\end{array}$} & \multirow{2}{*}{$\begin{array}{c}\text { Total wear } \\
\text { coefficient } \\
\mathrm{kN} \cdot \mathrm{rad}\end{array}$} \\
\cline { 3 - 4 } & & directive & lateral & \\
\hline 1.0 & 4 & 27.3 & -9.38 & 9.616 \\
\hline 2.0 & 4 & 12.23 & -15.15 & 9.381 \\
\hline 2.0 & 2 & 31.2 & -12.74 & 2.482 \\
\hline
\end{tabular}

Based on the results of presented calculations, the following conclusions can be drawn. The factor that mainly determines the dynamic processes during movement of a vehicle in the short radius curves, which have track irregularities in the plan, is the radius of the total curve.

$$
R_{c}=\frac{R_{c r} \cdot R_{n e r}}{R_{c r}+R_{n e r}}
$$

where $R_{c r}$ - curve radius (m); $R_{n e r}$ - radius of the irregularity (m).

If irregularity in plane view, which is described by equation (1) is adopted, value $R_{n e r}$, can be determined as follows:

$$
R_{\text {ner }}=\frac{L^{2}}{2 \cdot a_{\text {ner }} \pi^{2}}
$$

\section{Conclusions}

According to the results of the studies, if a total length of irregularity is $20 \mathrm{~m}$ and an amplitude is $23.3 \mathrm{~mm}$ (inequality of grade 4), its minimum radius will be $217 \mathrm{~m}$, and if these irregularities are in a circular curve of $300 \mathrm{~m}$, the total curve radius will be $126 \mathrm{~m}$. When a freight car of type $18-1000$ is moving at a speed of $70 \mathrm{~km} / \mathrm{h}$, the total value of the lateral wear coefficient increases from $0.252 \mathrm{kN} / \mathrm{rad}$ (track without irregularities, Table 1) to $17.219 \mathrm{kN} \cdot \mathrm{rad}$, i.e., 68.3 times, while when the wheel flange hits the rail, the value of the directive forces will exceed $380 \mathrm{kN}$ for wooden and $425 \mathrm{kN}$ for reinforced concrete sleepers. However, no speed limits are established for such inequalities. According to the data, dynamic effects on the track with the irregularities in plan view depend not only and 
not so much on the value of unbalanced acceleration, but on the impact force and the angle of attack of the wheel flange on the rail.

\section{References}

1. O. M. Darenskiy, Theoretical and experimental studies of operation of railway tracks of industrial transpor, (Kharkiv, 2011)

2. E. I. Danilenko, The rules of strength and stability calculation of the railway track, 168 (Transport Ukrainy, 2006)

3. M.F. Verigo, Vzaimodeystviye puti i podvizhnogo sostava v krivykh malogo radiusa $i$ bor'ba s bokovym iznosom rel'sov i grebney koles (Moscow, 1997)

4. O.P. Ershov, Dinamicheskaya otsenka otstupleniy v soderzhanii zheleznodorozhnogo puti i dal'neysheye yeye sovershenstvovaniye (Moscow, Transport 1989)

5. J. Herian, Achievements in Materials and Manufacturing Engineering, 49, 71-81 (2011)

6. H. Baluch, Diagnostyka nawierzchni kolejowej (Warszawa, 1978)

7. B. Lichtberger, Track Compendium. Formation, Permanent Way, Maintenance, Economic (Hamburg, Eurailpress, 2005)

8. J. Xu, P. Wang, L. Wang, Advances in Mechanical Engineering , 8, 1-14 (2016)

9. R. Matching, Railway Track \& Structures, 10, 2-3 (2016) 